\title{
Evaluation of Market Demand for Alternative Poultry Feeds in Nigeria
}

\section{OKO E.C ${ }^{1 *}$, AHAOTU E.0 ${ }^{2}$ and Lawal $\mathrm{M}^{3}$}

${ }^{1}$ Department of Agricultural Technology, Akanu Ibiam Federal Polytechnic, Unwana - Afikpo, Ebonyi State, Nigeria

${ }^{2}$ Department of Animal Production and Health Technology, Imo State Polytechnic Umuagwo, Nigeria

${ }^{3}$ Department of Agricultural Education, Federal College of Education Katsina, Katsina

State, Nigeria

*Corresponding Author: OKO E.C, Department of Agricultural Technology, Akanu

Ibiam Federal Polytechnic, Unwana - Afikpo, Ebonyi State, Nigeria.

E-mail: emmaocy150@protonmail.om
Received: June 16, 2021

Published: July 21, 2021

(C) All rights are reserved by OKO E.C., et al.

\section{Abstract}

Feeds constitute $70 \%$ of the cost of poultry production and of this, proteins constitute the highest cost. Finding cheaper alternatives to existing protein sources would improve efficiency of poultry production. Development and promotion of insect protein- based poultry feeds is assessed. It was observed that insect-based protein sources could significantly supplement cum replace fish meal which is the major source of feed protein. The market for conventional protein was expected to switch from fish to complete substitution with insect sources. The study main objective was to analyse demand, market size and trends of current conventional and sources of poultry feed proteins in Nigeria and make projections. The study was conducted in Imo, Edo and Kano states, Nigeria. The bulk of data was from secondary sources and primary data from formal survey of farmers and poultry value chain actors. Aggregate demand for insect feed ingredients for poultry feed was 5382 metric tons on dry matter basis at $50 \%$ rate of substitution of conventional protein. Projected demand for poultry feed proteins was 11,550 metric tons in the next 5 years. Insects had a strong potential for incorporation into poultry feeds.

Keywords: Consumer Tastes; Edible Insects; Protein Feed Substitutability; Fish; Soya Beans

\section{Introduction}

Ayo - Enwerem et al., (2017), revealed that chickens heavily consume manufactured feeds as compound concentrates or protein enriched value-added cereal bran or oil seed by-products on a daily basis. Is-Haaq et al., (2018) stated that feeds constitute over 70 per cent of the cost of production in such enterprises. Ononiwu et al., (2018), noted that chicken will only grow and perform to the extent they receive proper nutrition. If compromised, feed quality will affect feed consumption and can cause disease and nutritional deficiencies. Protein constituted the highest cost item in poultry feeds, thus finding alternatives would promote greater poultry production for both large scale commercial and smallscale producers (Okonkwo and Ahaotu, 2019). Reduction in cost of production of such feed will make cheaper protein rich food more available to a broader human population (Odey et al., 2019). Under free ranging chicken production systems, insects within the ecosystems are a key feed resource for many poultry species. Extensively managed village chickens move around gardens, green fields, open up top soils and litter to search for grasshoppers, crickets, cockroaches, termites, worms and their larvae that they 
feed on. Insects such as lice, cicadas, desert locusts, aphids, common housefly maggots (Musca domestica), flies, bees, stink bugs, scale insects, psyllids, beetles, fleas, wasps, domesticated silkworm, caterpillars and ants could be considered as animal protein feed ingredients for specific intensive commercial poultry production systems. This study was focused on assessing the potential market for insect protein in commercially produced poultry feeds.

It was observed that insect-based protein sources for poultry feed could significantly supplement or even replace fish meal which is the predominant source of feed protein used (Nkwocha et al., 2018). The market for conventional protein fish species was expected to be substituted with insect feed. When the location, time period and marketing effort of a product are defined, market demand of the product would constitute the total volume of that product or service that would be bought by a consumer group. Market demand can depend on environmental factors as well as the sales of related products, services and the existing economic conditions (Adewale et al., 2018).

Insect protein-based feed for poultry is a new feed product being researched on with the aim of producing low cost poultry feeds which will help farmers to lower their cost of production. Being a new product, a market demand analysis is necessary to understand its market potential. To determine the market demand of insect protein-based poultry feed, the market demand of the current poultry feed was analysed. The study viewed the followings as objectives: analyse the demand, market size and trends for conventional sources of poultry feed proteins in Nigeria at present, and also providing a current situation and make projections into the future and analyse the opportunities and threats for transfer and adoption of insects as protein sources in feeds.

\section{Materials and Methods}

The study was conducted where there are high concentrations of commercial poultry (small, medium and large scale). The study collected several data types based on several approaches. Secondary data consisted of reports and articles on works done on poultry feed in Nigeria. Key informant interviews were done with stakeholders knowledgeable in the poultry feed industry. Data were captured using semi-formal, structured formal standard and check lists.
Household survey sampling procedures

Multi-stage, stratified and purposive sampling techniques were used to identify respondent firms. In poultry farming sub-sectors data were triangulated and complemented using the data collection techniques shown below (Table 1).

\begin{tabular}{|c|c|c|c|}
\hline & $\begin{array}{c}\text { Married/ } \\
\text { cohabitation }\end{array}$ & $\begin{array}{c}\text { Single/ } \\
\text { divorced/ } \\
\text { widowed }\end{array}$ & \\
\hline & $(n=139)$ & $(n=43)$ & \\
\hline Variables & Mean \pm SD & Mean \pm SD & P-value \\
\hline Age (years) & $72.1 \pm 5.0$ & $74.5 \pm 5.6$ & 0.008 \\
\hline Male (yes in \%) & 46.8 & 25.6 & 0.014 \\
\hline Higher education (yes in \%) & 23.9 & 14.0 & n.s. \\
\hline Smoking (yes in \%) & 5.8 & 9.5 & n.s. \\
\hline Alcohol (yes in \%) & 84.9 & 71.4 & 0.048 \\
\hline Fish oil (yes in \%) & 51.1 & 53.8 & n.s. \\
\hline LTPA (h/week) & $5.9 \pm 5.4$ & $6 \pm 6.9$ & n.s. \\
\hline Number of medications & $2.1 \pm 1.6$ & $1.7 \pm 1.3$ & n.s. \\
\hline BMI $\left(\mathrm{kg} / \mathrm{m}^{2}\right)$ & $28.7 \pm 4.7$ & $28.8 \pm 5.1$ & n.s. \\
\hline Lean body mass $(\mathrm{kg})$ & $45.9 \pm 9.9$ & $44.4 \pm 7.7$ & 0.001 \\
\hline Grip strength (lb) & $66.4 \pm 19.7$ & $53.5 \pm 13.7$ & 0.001 \\
\hline 6MWD (m) & $470 \pm 75$ & $437 \pm 79$ & 0.013 \\
\hline Lumbal BMD (z-score) & $1.26 \pm 1.80$ & $0.29 \pm 1.93$ & 0.016 \\
\hline Femur BMD (z-score) & $0.39 \pm 0.95$ & $0.33 \pm 0.97$ & n.s \\
\hline Total BMD (z-score) & $1.11 \pm 1.18$ & $0.70 \pm 1.26$ & 0.050 \\
\hline PTH (pg/mL) & $45.8 \pm 18.4$ & $50.5 \pm 23.3$ & n.s. \\
\hline 25-OH-vitamin (nmol/L) & $66.9 \pm 26.8$ & $56.1 \pm 25.5$ & 0.022 \\
\hline
\end{tabular}

Table 1: Baseline characteristics of the participants $(\mathrm{N}=182)$.

Estimation of demand and market size of poultry feeds

Demand of poultry feed is determined by existing poultry populations multiplied by their feed intake in a production cycle 
(Onyekwere., et al. 2016). It is understood that both the number of farmers who mix their own feed and those who do not mix feed obtain their animal protein sources from the open market. Data capture focused on key animal protein ingredients used to mix the feed.

Trends in poultry feed availability

Information on seasonal availability in feed ingredient availability and price trends was obtained from feed processors, farmers and silver fish bulkers and bulk breakers at fish landing sites. Information captured reviewed annual trends and seasonal trajectory in availability and prices observed over the past 5 year period. Information collected centered on annual sales, seasonal changes in sales, volumes/quantities of different ingredients used seasonally and annually. The data were analysed to determine the trends and the progression of the fish market and insects' substitutes over time as well as the size of the market. In addition, farmers interviewed provided information on most popular poultry feed brands as well as the retail prices. The price information combined with feed volume estimates provides an approximation of the current and potential demand of the poultry feeds markets in the country.

\section{Sampling frame of poultry farmers}

Sampling of poultry feed market demand analysis study was done using two strata- sampling frame with focus being placed on two categories: Poultry farmers and Feed processors/suppliers. These were selected from Imo State, Edo State and Kano State, Nigeria. In this study, statistical rigour was not the key driver of the analysis. This implied that representativeness rather statistically large samples prevailed.

Prospects for transfer and adoption of insects as protein sources in feeds

Key informant interviews were conducted in the study area to explore Strengths, Weaknesses, Opportunities and Threats (SWOT) for transfer and adoption of insects as protein sources in feeds. Key informants included State Veterinary Offices (SVOs), State Production Offices (SPOs), farmer leaders, Community Development Offices (CDOs) and representatives of feed processors and feed ingredient suppliers.

\section{Results and Discussion}

Demand estimation for poultry feed

Demand estimation was calculated at annual basis. The key parameters used in its estimation are presented in table 2.

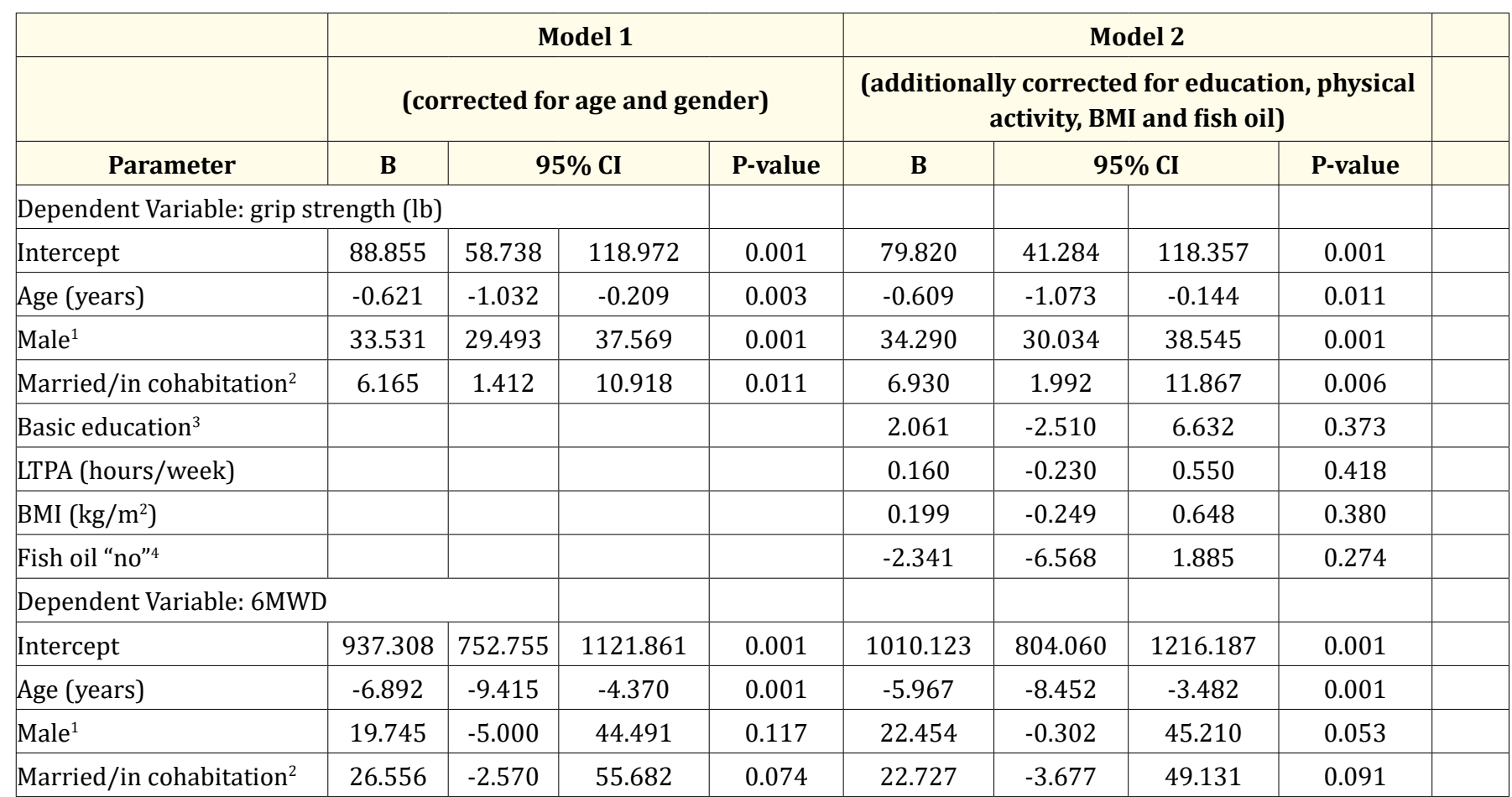




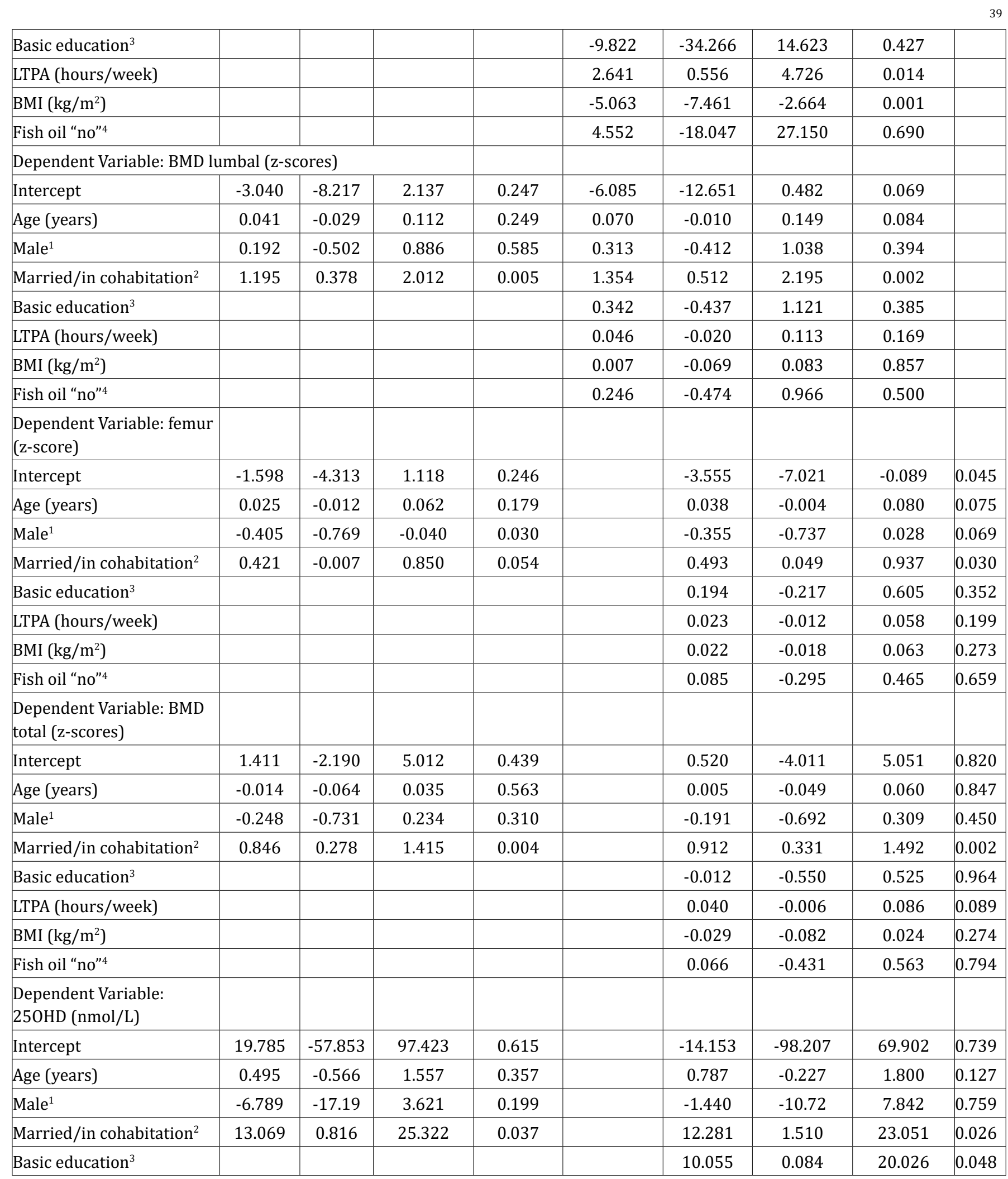




\begin{tabular}{|c|c|c|c|c|c|c|c|c|}
\hline LTPA (hours/week) & & & & & 1.615 & 0.764 & 2.465 & 0.001 \\
\hline BMI $\left(\mathrm{kg} / \mathrm{m}^{2}\right)$ & & & & & 0.102 & -0.876 & 1.080 & 0.836 \\
\hline \multicolumn{9}{|l|}{$\begin{array}{l}\text { Dependent Variable: PTH } \\
(\mathrm{pg} / \mathrm{mL})\end{array}$} \\
\hline Age (years) & 0.522 & -0.296 & 1.340 & 0.209 & 0.217 & -0.654 & 1.087 & 0.623 \\
\hline Male $^{1}$ & 2.176 & -5.846 & 10.198 & 0.592 & 1.250 & -6.719 & 9.218 & 0.756 \\
\hline Married/in cohabitation ${ }^{2}$ & -8.476 & -17.92 & 0.966 & 0.078 & -8.985 & -18.23 & 0.261 & 0.057 \\
\hline Basic education $^{3}$ & & & & & 4.781 & -3.779 & 13.341 & 0.271 \\
\hline
\end{tabular}

Table 2: Parameter estimates derived from multivariate GLM describing the differences between participants being married/in cohabitation $(n=139)$ vs participants being divorced/single/widowed $(n=43)$.

${ }^{1}$ as compared to female; ${ }^{2}$ as compared to single/divorced/widowed; ${ }^{3}$ as compared to higher education; ${ }^{4}$ as compared to fish oil "yes"

Protein sources used in manufacture of poultry feeds include full fat soya, solvent extracted soya and fish (Ahaotu., et al. 2018). The total quantity of protein used ranged from 2950 tons to 3550 tons between 2012 and 2015. Of this the proportion of fish ranged from 7 per cent to 28 percent. It is therefore estimated that the proportion of fish in the protein source for feeds is about 18 per cent.

Computation of national demand for animal protein in chicken feed

Technical coefficients used in the computation of broiler and layer feeds are outlined.

The total fish and poultry protein annual requirement are estimated at 10,740 metric tons for commercial broilers, layers and farmed fish. If rate of substitution of 50 per cent is anticipated the demand for insect feed ingredients would be 6500 metric tons on dry matter basis. Of this, the proportion of insect feed ingredients for poultry feed equals to 5382 metric tons.

Current and projected poultry and fish feed proteins (Tons) in Nigeria

The bulk of protein is obtained from soya bean (plant protein) and fish (animal protein).
Information on the major sources of protein and challenges with fish as animal protein revealed the following: There are seasons when fish is scarce on the market (Ahaotu., et al. 2019). This is attributed to two causes. Whenever the moon light is strong it tends to cause interference with the lights flashed on the lake to attract fish at night (Tripathi., et al. 2017). Besides, there are cases when demand for fish is high.

This coincides with peak production cycles for layer and broiler production. This is mostly during months of April to July and December to January (Uzoma., et al. 2019).

Analysis of strengths, weaknesses, opportunities and threats (SWOT) for transfer and adoption of insects as protein sources in feeds

As a result of managing the high cost and scarcity of protein sources more so the animal protein ingredients people have tried to substitute fish with houseflies, cockroach, maggots, ants, worms and grasshoppers.

The biggest constraint has been mass rearing of these alternative sources. Besides, there is competition with humans for some of these alternative sources particularly the case of white ants and grass hoppers as food. In addition, some processors use 
blood meal but this one is also not readily available and is also expensive. Soya bean (main source of plant protein) is considered to be next to fish as animal protein especially given that soya cake has high proteins. If it is used in large amounts the requirements for fish in the feed reduces. Other feed processors import animal protein to bridge the gap of not having enough fish. In order to get integrated in the process, feed value chains and poultry product food supply chains a range of demand, supply; cultural and socioeconomic factors were considered. These included availabilities of insects; prices of insects' substitutes, and competing ingredients; potential for entry given existing market structure, conduct and performance; proportion of population taking poultry and their products, and consumer tastes and preferences; cultural norms and values. Whereas some of these accelerate uptake and adoption of insects as protein sources in feeds others will disable the process. Below is a set of strengths, weaknesses, opportunities and threats (SWOT) for transfer and adoption of insects to replace fish as protein sources in feeds.

\section{Strengths}

When used as ingredients in feed, insects can provide the necessary animal protein and have the potential to lower cost of feeds. These insects can be bred and bulked in large quantities (maggots, crickets, cockroaches) using low cost substrates. Processors are positive to the use of the insects as they believe that many customers are indifferent about specific protein sources used as ingredients Demand for poultry products in Nigeria is very strong. Derived demand for feed ingredients is hence very high. Some companies have tried and gained necessary skills and interest in incorporating insects in poultry feeds.

\section{Weaknesses}

Some farmers think, if insects used happen to be a taboo to some people, such consumers may decline to eat the chicken produced. Farmers are somewhat negative on use of maggots - an intermediate stage of houseflies - this may not go well with the customers. Mass production of required quantities of insects to substitute fish requires skill and technologies that many scientists and feed manufacturers do not have the markets, distribution channels and consumption patterns and value chains for fish are already developed unlike those for insects.

\section{Opportunities}

There is a wide range of naturally existing indigenous tropical insects that can be harnessed. Some insects (grasshopper and flies can seasonally be harvested from the wild in large quantities the same way fish is harvested. Consumers are aware that free range chickens and capture fisheries normally feed on insects. Fish is generally scarce. Its availability is often seasonal and tends to become very expensive. This leaves a gap for substitutes like insects to enter the feed value chains'.

\section{Threats}

Price discrepancies may not feature due to scarcity of fish but rivalry among competing producers will ride on consumer tastes regarding actual insect used (maggots - grasshopper misgivings). Present attitude that fish is the best animal protein source will sustain competition from its substitute products namely the insects. Some insects such as grasshoppers, termites, white and black ants are delicacies and widely eaten by human population. This will impose competition besides some cultural conflicts on their usage. Inclusion of insects may change the taste and flavour, texture and cooking qualities of poultry products [1-12].

\section{Conclusion}

Feed protein ingredients for poultry feed is largely based on soya and fish meals. The two feed sources have seasonal availability, highly priced leading to high feed costs. Poultry naturally incorporate insects in their rations. Besides, farmers use insects such as white ants and termites to feed chickens. In addition, processors have attempted to lower protein feed costs by incorporation insects in their rations but are frustrated by mass bulking and sustainable production technologies.

\section{Bibliography}

1. Adewale IT., et al. "Serum Biochemical Indices and Haematological Profiles of broiler Birds Fed Varying Levels of Biscuit Waste Meal Based Diets". International Journal of Animal Science 2.5 (2018): 1032-1035.

2. Ahaotu EO., et al. "Climate Change in Poultry Production System - A Review". Acta Scientific Agriculture 3.9 (2019): 113117. 
3. Ahaotu EO., et al. "Effects of Amaranthus spinosus (Green) Leaf meal on the Performance of Hubbard Broiler Chicks". Macedonian Journal of Animal Science 8.2 (2018): 77-80.

4. Ayo-Enwerem MC., et al. "Growth performance of starter broilers fed diets containing red sandalwood (Pterocarpus santolinoides) leaf meal". Direct Research Journal of Veterinary Medicine and Animal Science 2.4 (2017): 106-109.

5. Is-Haaq AT., et al. "Replacement value of Puerairia phaseoloides leaf meal for soya bean meal on the Performance and carcass evaluation of starter broilers". Journal of Research in Microbiology and Biotechnology 1.1 (2018): 5-9.

6. Nkwocha GA., et al. "Performance and Hematological Profile of Broiler Chicks on Toasted Tiger Nut (Cyperus esculentus) Treated With Bakery Yeast". Proc. 43rd Annual Conference of the Nigerian Society for Animal Production, March 18th - 22nd 2018, FUT Owerri, Nigeria (2018): 484-487.

7. Odey MA., et al. "Effect of Supplemental Moringa oleifera Leaf Meal on Performance of Starter Broiler Birds". International Journal of Research in Agriculture and Forestry 6.4 (2019): 1-9.

8. Okonkwo S and Ahaotu EO. "Management of Laying Birds in Deep Litter and Battery Cage Systems In Orlu Local Government Area of Imo State, Nigeria: A Comparative Study". Journal of Agricultural, Biological and Environmental Sciences 6 (2019): 20-27.

9. Ononiwu CC., et al. "Effects of Bambara Nut Sievate Fortified Exogenous Enzyme on Performance and Carcass Characteristics of Finisher Broiler Birds". Proceedings of the 20th Biennial Conference, Ghana Society of Animal Production (GSAP), 1-5 August, 2017. Sasakawa Centre, University of Cape Coast, Ghana (2017): 73-80.

10. Onyekwere MU., et al. "Effect of dried cocoyam tubers (Colocasia esculenta) meal on growth performance and blood serum mineral profile fed broiler starter". Proc. 21st Ann. Conf. Animal Science Association of Nigeria. Porthacourt, Rivers State. Nigeria, 18th -22nd Sept, (2016): 184-189.

11. Tripathi A., et al. "Understanding Integrated Impacts of Climate Change and Pollution on Ganges River System: A Mini Review on Biological Effects, Knowledge Gaps and Research Needs". SM Journal of Biology 3.1 (2017): 1017-1027.
12. Uzoma U F., et al. "Response of High Dietary Energy Profile Meal from Processed Maize Products on Performance Parameters and Egg Quality of Shaver Brown Laying Birds". International Journal of Research in Agriculture and Forestry 6.1 (2019): 29-37.

\section{Volume 5 Issue 8 August 2021}

(C) All rights are reserved by OKO E.C., et al. 